DOI: $10.1515 /$ hssr -2017-0015

HSS VI.2 (2017)

\title{
Poetic Style and Social Commitment in Niyi Osundare's Songs of the Marketplace
}

Kadir Ayinde Abdullahi*

University of Ilorin, Nigeria

\begin{abstract}
This essay studies some of the poetic devices employed by Osundare to project social commitment and vision in Songs of the Marketplace. It examines how the poet's deployment of style makes his poetry more accessible to a larger audience than that of his predecessors. Like the oral traditional performance, his poetry employs rich Yoruba oral literary devices in a way that is unique and glaringly innovative. Osundare's radical poetic style has a clearly defined concept and role. It is also central to the resolution of the polemics of governance and politics in society. The pervasive theme of the collections remains a serious concern for hope out of the decadent situation that has eaten deep into the fabric of our social existence.
\end{abstract}

Keywords

Osundare, Songs of the Marketplace, poetic style, oral tradition, politics

\section{Introduction}

This paper studies the poetic style and vision of nation-building in Niyi Osundare's Songs of the Marketplace. The essay focuses on the specific way in which cultural production has contributed to the understanding of the problem of governance in the post-independent Nigerian nation. In the field of African literature, interrogation of this nexus has come to be

\footnotetext{
* Department of English, University of Ilorin, Nigeria, PMB 1515; email: kadiraabdul@yahoo.com
} 
known as radical aesthetics. Songs of the Marketplace addresses a wide range of issues bordering on corruption, poverty and administrative ineptitude. Osundare's poetic style is ideologically infused with the materialistic perspective of society as argued by Karl Marx. Through an alternative poetic style, he aptly re-visits the foundation of our nation and ruthlessly depicts the failure of the post-independence regimes. His poetry also depicts the predicament of the less privileged members of the Nigerian society. In Songs of the Market Place, there are instances of poetic style which consciously gesture towards a desire for the order and form so long promised by the ideal of nation building.

The social relevance of Songs of the Marketplace to the society as a mirror of political and economic sterility and the call for spiritual re-vitalization cannot be over- emphasized. This is why Osundare $(1983,115)$ affirms that:

Literature is part of the structure of the society; it may simply record the kind of society the writer knows - its values, problems, structure, events etc. or it may attack this very society and its present evils. Literature more often embodies the writer's evaluation of his work or illuminates its possibilities.

Osundare's postulation shows how sensitive literature is to society, not only in employing poetry for depicting happenings but also as an advocate of social change and nation building.

\section{Emergent Nigerian poets}

The emergent poets are the second generation of Nigerian poets namely Tanure Ojaide, Niyi Osundare, Odia Ofeimun whose poetry is immersed in the Marxist critical tradition. Marxist insurrection in Nigerian creative practice emerged from the late 1970s. The emergent poetry is preoccupied with the criticism of oppressive systems, the identification of the people responsible for the failure of nation building as well as the promotion of an alternative system perceived to be liberating. According to Aliyu (2012: 125) several critics have attempted to give emergent writing a brand name. For instance, Akinwale (1993) refers to it as 'protest'. Gbilekaa (1997) calls it 'radical' while Ododo (2004) adopts the term "re-creative". The high point of difference between the works of the earlier and emergent poets is 
the adoption of a new poetic style and revolutionary ideology. Ojaide cited in Okunoye (2008: 3) states clearly that:

Modern African poetic aesthetics are unique in possessing a repertory of authentic African features. This authenticity manifests itself in the use of concrete images derived from the fauna and flora, proverbs, indigenous rhythms, verbal tropes and concepts of space and time to establish a poetic form. The mere fact that foreign languages are used could occasionally create discord in discourse but modern African poetry attempts to reflect indigenous rhythms. In fact, an authentic African world forms the backdrop of modern African poetry.

The emergence of modern African poets along with a new poetic revolution presents a dramatic departure from the Euro-Modernist Nigerian poetry of the first generation. The emergent African poetry champions a poetic innovation within the framework of what critics have described as alternative poetic tradition. The synthesis of Western and African oral literary forms is a laudable landmark in the corpus. The adaptation of local language and traditional speech patterns are distinguishing characteristics of the poetry. Niyi Osundare in particular strives for an effective way of communicating African poetic visions and African realities. Ojaide affirms this when he posits that "unlike in the 1960s when the poets were culturally obsessed, nature-oriented and universal, today, old and young poets are addressing their national issues more aggressively than before. In their desire to effect changes, they use the nation state as their starting point (Okunoye, 2008: 4). Osundare's poetic revolution marks him as a representative voice of this class. He leads the group in his commitment of liberating society and at the same time demystifying the task of interpreting poetry. His style and the themes tend to address the socio-political and economic adversity of our nation.

\section{Theoretical framework}

The paper adopts Marxist theory as a theoretical approach. As a utilitarian perspective of literature and society, Marxist ideology identifies social and economic factors in the conceptualization of the relationship between the bourgeois and the proletariat. Marxist philosophy upholds that a capitalist society perpetuates oppression of the less privileged class. 
The Marxist critic thus reacts to the various strata of social and moral decadence. The theory criticizes the political and economic deprivation and promotes the need for social change through revolution.

Marxist theory is grounded in dialectical materialism that stresses the economic survival of the competing classes. Karl Marx defines materialism as the struggle between bourgeoisies and proletariats as the mover of social change (Wumi, 1998: 200). Marxism believes that the historical development of society is an aftermath of the changing mode of socioeconomic productions. The struggle between the two indentified classes engenders social stratification. Shapiro defines social stratification as a process or system by which groups of people are classified into a hierarchical social structure (192).

The radical wing of Marxist critic is emerged in Nigerian critical practice in the 1970s. The literary critics operating within the Ibadan/Ife axis namely Biodun Jeyifo, Femi Osofisan, G.G Darah, Niyi Osundare, Ropo Sekoni were prominent. According to Okunoye (2008: 5), a ground breaking essay of Omafume Onoge entitled The crisis of consciousness in modern African Literature (1965) provides inspiration for modern poets in their campaign against the vices of social and economic contradictions. Ngara's Ideology and Form in African poetry (1990) and Udenta's Arts, Ideology and Social Commitment in African poetry (1976) are also among the few studies of African poetry in the Marxist tradition. Chidi Amuta's The Theory of African Literature (1989) is another enviable follow up. The Marxist analysis of African literature emphasizes the historical and social conditions which have given rise to African literature.

Osundare sets out in Songs of the Marketplace to re-define African poetry in terms of revolutionary posture. As a result of his concern for man in society, he advocates for the masses that are dominated and oppressed by political leaders. He writes to promote the interest of the teeming alienated and oppressed members of his society through a polemical poetry that could awaken their consciousness. He seeks to mobilize the numerous voiceless have-nots to the desire for social transformation. Osundare employs a series of novel poetic styles to communicate his vision of social change. He employs oral narrative laced copiously with Yoruba syntax. Musicality across rhythm is a prominent feature of his poetic compositions. This musicality 
...inform the poetic features of verbal, structural repetitions and parallelisms. Osundare in his own special way imbibes what some critics called the 'Agisymban' stylistic feature which is a characteristic of sound and drums, dancing feet and melody of tone (Nachafiya, 2008: 8).

His thematic preoccupations are of great relevance to the postindependence African states, particularly Nigeria, where the social fabric of the nation has been weakened by massive corruption and moral ineptitude. Emmanuel posits that:

There is that type of literature by which the writer rebels against societal values. He is the one that is sensitive to what is going on around him; one who wants a better deal for everybody. This is the kind of literature that becomes an instrument for social transformation. Its basic aim is to awaken the revolutionary consciousness in the majority of group of the society who are oppressed, exploited and deprived of good social living condition (2007: 85).

Osundare sets for himself the task of re-awakening the consciousness of the poor. His poetry expresses the ideal of social equity in our nation. This is in tandem with what Emmanuel further refers to as 'social advocacy' (2007: 107) By this, he refers to the works in which the writer's social vision is preoccupied with the welfare of the common masses and with struggling against social ills. Delap argues "that the ability of leading Nigerian poets like Osundare to attract audience through public performance has become significant at a time when Nigeria's political and economic morass has sidelined intellectuals and the academic community" (3). Interestingly, Osundare emerges as a touch-bearer of the new generation of Nigerian poets undeterred by the many obstacles they face. The ideological warfare between the poet and the rulers were open demonstrations of the inefficiency of independence in Nigeria. Biodun Jeyifo while justifying Osundare's revolutionary instinct posits that:

You will thus read in Osundare's volume sometimes humorous, often searing, and occasionally bitter and satirical but always vivid and metaphorically arresting evocations of episodes from our recent history and upheavals, triumphs and defeats of our struggles in Nigeria and other lands. You will 
encounter celebrations of defenders of the oppressed and the scourge and terror of the oppressors. Above everything else, the justification of the will to revolution in Osundare's poetry is based on a rigorous, sustained solicitude for one of the world's oldest producers: the peasant, those who till the soil and their quasi-mystical ties to the earth (1988: 316).

There has been a bad political system which engendered instability. There is an ever-widening gap between those who wallow in affluence and others contending with abject poverty. There was also a total neglect of vital public infrastructural base, scientific and technological development as well as an apparent flouting of codes of ethical conduct. Hence, Osundare's Songs of the Marketplace lends voice to this debasing scenario. The poetry is vociferous in its recommending the alternative of socialist transformation of society and the rejection of international monopoly capital.

\section{Osundare's social vision}

Poetically, Osundare reflects his concern with the socio-economic woes in Nigeria. He employs novel styles and imageries that create an avenue for expressiveness and social transformation. His poetry deploys suitable metaphors to describe the unnatural relationship between the rich and the poor. According to Nachafiya, "Osundare pioneers a campaign against obscurantism by writing Songs of the Marketplace to propagate and celebrate what many critics came to believe was an over-asserted and unrealistic leap. The void, so seemingly created at kenosis in this context, gave Osundare the leverage to employ a befitting poetic medium to join the emerging new voices in poetry" (2008: 4). His interest in an innovative poetic style is well defined in his choice of language and style. The Songs of the Marketplace seek to redefine poetry as

a life spring

Which gathers timbre

The more throats it plucks

Harbingers of action

The more mind is stirs (1) 
The choice of language deliberately aims to reject the obscurity of the earlier Nigerian poetry and creates wider accessibility for audience. The persona maintains that:

Poem is

No oracles kernel

For sole philosopher's stone

Poetry

Is

Man

Meaning

To

$\operatorname{Man}(1-2)$

This stanza is a further indication of Osundare's aspiration to break language barriers in poetic rendition. Through language simplification, he moves modern African poetry from royal court to the parlance of common men. Songs of the Marketplace reflects the image of a market arena where the poet can reach out to a majority of down trodden individuals who gather for buying and selling activities. In the marketplace, the crowd is large so messages are easily spread. The poet deliberately jettisons the usual royal arena for rendering songs but chooses the marketplace. The poem thus reads:

My words will not lie like eunuch wind

Fluttering leaves in a barren forest

My words will climb the tree of wisdom

Feed multitudes with fruits of thought

And plant the earth with potent seeds for

I have woken up this morning with a song in my throat

the chorus echoes across the world.

The poet seeks to create awareness by conscientizing the multitude of the voiceless masses. The poem sets to mobilize the people towards expediting the process of redemption. Since the categories of people who patronize the marketplace are the down-trodden, those who suffer the brunt of socio-political vices, the market becomes the appropriate avenue 
for creating revolutionary awareness. Rather than promote the powerful warlord, the persona targets the consciousness of the poor whose revolutionary instinct the poetry is intended to ignite. The poet insists that:

Poetry is

The hawker's ditty

The eloquence of the song

The lyric of the marketplace

The luminous ray

On the grass's morning dew

The stanza explains the duty which the poet sets for himself on behalf of his community. He renders himself as the voice for the voiceless. There are obvious deployments of poetic elements that express the predicaments of the poor in the collections such as 'Udoj'i, 'Excursion', 'Siren' 'University Congregation' as well as 'Reflection' among others. For instance 'Excursion' is a long poem, which is a poetic irony for the adventure that the persona undertakes. It renders an account of different places where life means different things to different individuals. The poem is full of images of disease, poverty, deprivation and want that are symbolic features of life and existence in Nigeria.

In a poem of similar thematic concern 'Olowo Debate Talaka' in Songs of the Season, Osundare catalogues the various classes of the deprived and ranges of afflictions in Nigerian society. It decries the unhealthy relationship between the rich and the poor. The poem reads:

Olowo: Call me hyena, call me leopard

Call me the bloodiest in a tribe

Of monster beasts;

But this I know;

A leopard labours hard for his daily prey;

I work hard for every Kobo in my bank.

Talaka: Hard work! Hard work!

The lazy hobby-horse of the rawdy rich!

Hard work! Hard work! 
The insufferable drudgery of loafing barons

Hard work! Hard work!

The suffocating sweat of chilling Benzes

Hard work! Hard work

The toilsome junnkets in London and Yokohama

Hard work! Hard work!

In busy beds, and rivers of champagne

Hard work! Hard work!

Of absentee barons and surrogate fortunes

Hard work! Hard work!

Monkey dey work, baboon de chop

Money man, how many hands do you have?

How many heads stand on your neck?

The dialogue between the rich and the poor in the above stanza clearly illustrates the heartless attitude of the privileged class of elites in a society where a few bandits found themselves in a position of power and amass illicit wealth to the detriment of public welfare. Stylistically, the poem uses repetition of phrases, lines and structures to reinforce the lyrical tone of the song. Rhetorical questions are some of the devices employed in the last two lines of the second stanza to produce the desired meanings. This is what Ezenewa-Ohaeto refers to as "cinematic Presentation of the sights and sounds of people and places who are not used to fashion lyrics of joy but that of pain (1998: 156).

Osundare uses breath-space pauses found in oral performance to heavily descend on visionless leadership in 'Udoji' which the poet uses as a topical allusion to the pay-increase of Nigerian workers in 1975. The persona seems to opine that the pay produced inflation that sets the country on the path of economic meltdown. Songs of the Marketplace catalogues the predicament of children and women who continue to wallow in abject penury despite the abundant resources in the nation. The persona sings about the group of women who scavenge for food in garbage cans. He says:

In city fringes pregnant women rummage garbage leaps for 
The rotting remnants of city tables

above, hawks and vultures hovering for their turn.

This stanza is an indicative that through selfishness and illicit wealth acquisition, the ruling class reduces citizens to beggary. The choice of language here reflects the deplorable condition that people found themselves in as a result of the recklessness of their leaders. Osundare, like other socialist poets of his generation, believes that the situation can be remedied through a process of conscientization and eventual collective struggle. To him, this should be the poet's artistic ideological commitment in a society that is socially and economically stratified. In an interview he granted to Weekend Concord, he maintains that:

At the personal and public level, I see a lot of problems around and I've always seen some kind of ray of light at the end of the tunnel. What I say is, if we have gone through 500 years of dehumanization and we are still here, there is no reason we shouldn't pull ourselves up and leap into the 21st century.

is a poet whose The rhythm of Osundare's poetry is languorous and pedestric. His poetry uses African aesthetics immanent in his Yoruba culture such as African percussion like the flute and the drum to enact an avant-garde literature of socio-cultural and political commitment. He is a poet who aesthetically transforms written poetry to oral performance with participatory audience drawn from among the down-trodden masses; and in the process, words, music, setting and message transform to collectively conscientize and revolutionize the people for social redemption. His poetry is nothing but radical both in content and form using one to complement the other. In the hand of Osundare, there is a remarkable manipulation of new aesthetics in poetry which concerns the use of language or diction, thematic perception and form.

\section{Conclusion}

This essay studies the poetic style of Niyi Osundare's Song of the Marketplace. It reveals how the poet seeks to re-orient a novel trend in modern African poetry and engage many forces of oppression. This style and theme run through all the collections. The poems vividly depict the socio-economic issues in Nigeria by deploying appropriate images which 
translate to how politics is being used to entrench poverty and enrich a cabal. The relevance of poetry in re-moulding the mind sets of any group of people has been well explored by Niyi Osundare.

\section{References}

Aliyu-Ibrahim, F. R. (2012). "Images of the woman in Olu Obafemi's Illuminations: Songs, Dances from the Belly of Time" Gender Politics: Women's Writing and Film in Northern Nigeria. (EDs) Yerima Ahmed and Aliyu Saeedat. Ibadan. Kraft Books Ltd.

Dimgba, I. (1991). Weekend Concord. Vol.3 No 29 Saturday $7^{\text {th }}$.

Delap, M. Nigerian Poetry-Black Star or Black Hole? Poetry Online

Ezenwa-Ohaeto C. (1998). Nigerian Poetry and the poetics of Orality. Bayreuth: Bayreuth African Studies.

Emmanuel, A.M. (2007) "The Literature of the People: A Critical Appraisal of Selected Plays since Independence". Language and Literature in Developing Country: Essays in Honour of Professor B.O.A Okupe. Onitsha. Africana-First.

Jeyifo, B. (1988). "Introduction to Niyi Osundare". In Perspective on Nigerian Literature 1900 to the Present. Vol. II (ed) Yemi Ogunbiyi, Lagos. Guardian Books.

Okunoye, O. (2008). The Critical Reception of Modern African Poetry. File//c/Document/20/setting/5/gb/my/Document. retrieved 12 September, 2016

Osundare, N. (2009) "Education and Sustainable Development" The Guardian. Lagos. The Guardian Newspaper, Sunday March $1^{\text {st }}$.

Osundare, N. (1983). Songs of the Marketplace . Ibadan. Heinemann Educ. Books Ltd.

Osundare, N. (1990). Songs of the Season. Ibadan. Heinemann Educ. Books Ltd.

Nachafiya, A. (2008). N. Style and New Poetic Revolution in Niyi Osundare's Poetry. File//c/Document/20/setting/5/gb/my/Document. retrieved 12 September, 2016

Wumi, R. (1999). "Modern Literary Theory and Criticism" The English Language and Literature in English: An Introductory Handbook. Adegbija E (ed). Department of Modern European Languages, University of Ilorin.

\section{Biographical note}

Abdullahi Kadir Ayinde is currently a senior lecturer in the Department of English at the University of Ilorin, Nigeria. His area of research interest is African and Black Diaspora Literature. 